\title{
THE PROGNOSTIC VALUE OF ANTI CITRULLINATED PROTEIN ANTIBODY TEST IN RHEUMATOID ARTHRITIS
}

\author{
Safwat El Araby*, Ehab Abdel Azim Ahmad*, Hala Mohamed Raslan**, Ahmed \\ Fathy Ahmed*, Ahmed Fathy Abdelaziz***,Khaled Farg Sayd***, Mostafa Mohamed \\ Shaban*** \\ *Al-Azhar University, Faculty of Medicine, Rheumatology, Physical Medicine and \\ Rehabilitation department. \\ ** National Research Center, Medical division, department of internal Medicine. \\ ***Al-Azhar University, Faculty of Medicine, Clinical Pathology department.
}

\begin{abstract}
Background: Rheumatoid arthritis (RA) is a chronic, systemic inflammatory disorder that may affect many tissues and organs, but principally attacks synovial joints. About $1 \%$ of the world's population is afflicted by rheumatoid arthritis, women three times more often than men. Onset is most frequent between the ages of 40 and 50, but any age group can be affected.
\end{abstract}

Aim of Work : To study the value of Anti cyclic citrullinated protein (Anti-CCP) test as a predictor of disease course, disability, prognosis and response to treatment in Rheumatoid arthritis patients of a specific age group with regard to history, clinical and radiological findings. The results for Anti-CCP will be compared to Rheumatoid factor test. Patients: 80 female cases were collected from rheumatology outpatient clinics, with disease duration of 3- 5 years and age range from 35 to 40 years Methods: All cases underwent thorough history taking, clinical examination, radiological and laboratory assessment as well as disability and health assessment scoring. Each patient will undergo a quantitative test of Anti cyclic citrullinated protein (Anti-CCP) and Rheumatoid factor. Results : Our study showed that there was high significant relation between positive and negative RF and Anti-CCP titres. $(\mathrm{p}=0.0000)$ for the patients in the studied group. There was a high significant correlation between Anti-CCP and RF titres ( $\mathrm{r}=0.81, \mathrm{p}<0.05)$

Also there was a significant correlation between Anti-CCP and ACR disability class. In addition, there was a positive but not significant correlation between Anti-CCP and STLW score. (Clinical findings score- Swelling, Tenderness, limitation of movement, Warmth) and with VAS (Visual analogue scale) Conclusion: Our study found that AntiCCP has a reasonably good prognostic value, especially as regards disability and functional status prediction. It also showed that Anti-CCP is very comparable to Rheumatoid factor when comparing prognostic values. It is only slightly more indicative in terms of clinical, radiological and health assesment.

Keywords: Rheumatoid Arthritis, Anti-CCP, ACPA, Rheumatoid factor, prognosis, radiographic damage, disability, functional status.

\section{INTRODUCTION}

Rheumatoid arthritis (RA) is a chronic, systemic inflammatory disorder that may affect many tissues and organs, but principally attacks synovial joints. The process produces an inflammatory response of the synovium (synovitis) secondary to hyperplasia of synovial cells, excess synovial fluid, and the development of pannus in the synovium (Majithia and Geraci 2007). A high percentage of patients with rheumatoid arthritis have substantial titres 
of antibody to peptides containing citrulline, and citrullinated peptides are found in rheumatoid synovium (Yelin $\boldsymbol{e t} \boldsymbol{a l}$., 1999). The Anti citrullinated protein antibody (ACPA) tests, also known as the anti-cyclic citrullinated peptide (anti-CCP) antibody test, is an enzyme-linked immunosorbent assay that tests for the presence of antibodies that recognizes specific antigens containing citrulline (Schellekens et al., 1998). The specificity of anti-CCP is around $95-98 \%$ as regards undifferentiated forms of arthritis that do not develop into RA. $\operatorname{IgM} \mathrm{RF}$ is often found in the same patients, but with much lower specificity for RA. One study using a CCP1 assay showed a sensitivity of 55\% and a specificity of $97 \%$ for RA, when both anti-CCP and IgM RF were positive in the early stage of arthritis (Jansen $\boldsymbol{e t}$ al., 2002). Several observations have indicated that anti-CCP positive early RA patients may develop a more erosive disease than those without anti-CCP. Other investigators have confirmed this, and suggested the superiority of anti-CCP over IgM RF in predicting an erosive disease course. The use of anti-CCP results in the decision whether a patient should be treated aggressively at an early stage or not is an important area for research (Kroot et al., 2000).

\section{Methods}

This study was conducted on 80 Rhematiod patients were collected from Rheumatology outpatient clinics of Alhussein University Hospital, Sayed Galal University hospital and the National Research Center rheumatology clinic. The cases were diagnosed according to the 1987 classification criteria of the American College of Rheumatology (Arnett et al., 1988).

Inclusion criteria: 1- All cases were females.(there age ranged from 35-40).

2- All cases had disease duration of 3 to 5 years since the onset of diagnostic symptoms.

3- All cases were receiving steroid doses of 5 to $15 \mathrm{mg}$ /day in combination with Non steroidal anti inflammatory drugs and either Methotrexate (doses ranged from 7.5 to $17.5 \mathrm{mg} /$ week) or Leflonamide.

Exclusion Criteria: Pregnancy, DM, ischemic heart disease, hypertension, chronic liver disease, chronic kidney disease, other autoimmune diseases or any other chronic diseases.

All participants accept to participate in this study.

Thorough history taking and clinical examination were done for each case, clinical findings of local examination were made using the Swelling tenderness limitation of movement warmth "STLW" score system. The DAS28 score was calculated for all patients (Aletaha et al., 2004).

\section{DAS 28 Score:}

Disease Activity Score (DAS) (Van Der Heijde et al., 1993) provides a composite measure of disease activity based on joint counts, ESR, and patient global assessment of general health rather than measuring response. This is not dependent on baseline parameters to show a difference and therefore provides a more absolute measure of disease severity, which can be followed over time. The DAS28 based on joint counts of 28 joints. (Prevoo et al., 1995).

The collected scores were calculated using the following formula:

$\left[0.56 \times \sqrt{ }(\right.$ TEN 28) $]+[0.28 \times \sqrt{ }(S W 28)]+\left[0.70 \times\left(\right.\right.$ ESR after 1 hour in $\left.\left.\mathrm{mm}^{x}\right)\right]+[0.014 \times$ (patient's assessment in $\mathrm{mm}$ )] = DAS 28 score.

TEN28: Number of tender joints.

SW28: Number of swollen joints. 
ESR: Erythrocyte sedimentation rate.

The net score indicates the disease activity according to the following:

$\leq 3.2$ score indicates inactivity.

$>3.2 \leq 5.1$ score indicates moderate activity.

$>5.1$ score indicates very high activity. (Van Der Heijde et al., 1993),

Radiological assesment was performed using the Sharp score:(Van der Heijde modification) (Sharp et al, 1985. , Van Der Heijde D 1999.

The patient's disability status and abilities at the time of examination were determined based upon a health assessment questionnaire and the American College of Rheumatology revised criteria for functional status in RA, classification from class 1 to 4 (Hochberg et al.. 1992). All patients were given a score percentage. The Health Assessment Questionnaire (HAQ) was translated into Arabic to be applicable for use with Egyptian patients.

The following laboratory investigations were done:

\section{Blood sampling:}

Venous blood samples (random) were obtained from each subject in the study one $\mathrm{mL}$ was delivered into EDTA tube for CBC; $2 \mathrm{~mL}$ were delivered into tube containing trisodium citrate for ESR. The rest was left to clot, centrifuged, and the separated serum was divided in 2 aliquots one used for routine biochemical laboratory investigations (liver, kidney, CRP and random blood glucose) while the second aliquot was stored freezed at $-20 \mathrm{C}$ until used for determination of Anti CCP and RF.

The following laboratory investigations were performed to all patients participating in this study :

Erythrocyte sedimentation rate by Westergren method.

2- $\quad$ Liver, kidney function tests and Random blood sugar. (all were analzeyd by Hitachi Cobas C311 automated analyzer).

3- $\quad$ Complete Blood Picture by fully autmoated cell counter Sysmex Kx-21 N.

4- Quantitative determination of Rhumatiod factor by turbidimetry method using Kit of Spinreact.

5- $\quad$ Anti CCP antibodies (by enzyme linked immunosorbent assay for quantitative determination of anti-cyclic citrullinated peptide.

Kits: ORGENTEC Diagnostika GmbH.

Analyzer: Stat fax -2600 (ChroMate)

The principle of assay of anti-CCP antibody:

The anti-CCP antibody Kit is based on an ELISA method. The test utilizes microtitre plate wells coated with citrulinated synthetic peptides (antigen).

Diluted patients sample serum is applied to the wells and incubated. If specific antibodies are present, they will bind to the antigen in the wells. Unbound materials are washed away and any bound antibodies are detected by adding horse radish peroxidase (HRP) labeled anti-human IgG, followed by a second washing step and incubation with substrate. The presence of reacting antibodies will result in the development of colour, which is proportional to the quality of bound antibody, and this is determined photometrically.

\section{Statistical analysis of data:}

Statistics were done by computer using Epi - info. Software, version 6.04. A word processing, data base and statistics program (WHO, 2001).The tests used were: $\mathrm{X}$ mean, 
SD standard deviation: to measure the central tendency of data and the distribution of data around their mean. Student's t test: for testing statistical significant difference between means of two samples. Median: is a measure of central tendency when extremes of values are found in data. X2 tests (Chi square test) to test statistical significant relation between different variable or grades (qualitative data) or percentages. $\mathrm{Z}$ test to test statistical significant difference between two percentages. F "analysis of variance" (or ANOVA test) to test statistical significant difference between more than 2 means i.e. differences between 3 or more groups at the same time. Pearson's correlation test (correlation coefficient $r$ ) to test a positive or negative linear relationship between two variables (one dependent and the other is independent variable).

\section{RESULTS ANALYSIS:}

\section{Descriptive study.}

The present study was carried out on 80 Rheumatoid arthritis female patients diagnosed according to the 1987 American College of Rheumatology criteria. All cases had disease duration of 3 to 5 years since the onset of diagnostic symptoms. Their age ranged from 35 to 40 years old), (Mean age was $38.01 \pm 3.4$ ) The BMI (Body mass index) of the study group: (Mean $31.98 \pm 5.49$ ), (Range: 21.7 to 53.9) and Waist to hip ratio: (Mean=1.15 \pm 0.2 ), (Range: 0.82 to 1.75 ). Extra-articular manifestations were present in 55 cases $(68 \%)$ and subcutaneous nodules were present in 10 cases $(12.5 \%)$.

-DAS 28 score: (Disease Activity score): It had a mean value of 5.35, range from 2.02 to 7.35 in the study group.

-STLW score: (Swelling, Tenderness, And Limitation of movement, Warmth): It had a mean value of 29.5, range from 0 to 97 in the study group.

-Deformities: were present in 23 cases (29\%).

-Radiographic progression: Modified Sharp score: It had a mean value of 24.8, range from zero to 128 in the study group. (Table 1 ).

Table (1): Demographic data and medical history of the studied group (80 cases):

\begin{tabular}{|l|l|l|}
\hline Variables & \multicolumn{1}{|c|}{ Number of cases } & \multicolumn{1}{c|}{ Percentage } \\
\hline Onset & 35 & 45 \\
Acute & 45 & 55 \\
Gradual & & \\
\hline Course & 9 & 11.3 \\
Intermittent & 68 & 85 \\
Progressive & $3 \quad$ Mean & 3.7 \\
Steady & \multicolumn{1}{|c|}{ Range } \\
\hline Age /year & $38.01 \pm 3.4$ & 35 to 40 years \\
\hline Duration /year & $3.29 \pm 0.86$ & 2 to 5 years \\
\hline Weight/kg & $81.63 \pm 14.37$ & 42 to 145 \\
\hline Height /m & $1.59 \pm 0.07$ & 1.37 to 1.74 \\
\hline Waist circumference/cm & $98.2 \pm 15.42$ & 65 to 134 \\
\hline Hip circumference /cm & $87.74 \pm 17.68$ & 52 to 133 \\
\hline BMI(kg/m^2) & $31.98 \pm 5.49$ & 21.7 to 53.9 \\
\hline Waist / hip ratio & $1.15 \pm 0.2$ & 0.82 to 1.75 \\
\hline
\end{tabular}

\section{BMI: Body mass index}

Table 1 shows the studied group with respect to age, duration, weight, height, waist circumference, hip circumference, Body Mass Index, Waist /Hip ratio. The present study 
was conducted on 80 females of Rheumatoid arthritis. $45 \%$ were acute onset, $53.8 \%$ were gradual onset, $1.2 \%$ were insidious onset $11.3 \%$ were intermittent, $85 \%$ were progressive, and $3.7 \%$ were steady.

Anti-CCP and RF results:

- The mean value of RF titre in the studied group was $82.59 \pm 113.19 \quad \mathrm{IU} / \mathrm{ml}$, the range was $<8$ to $512 \mathrm{IU} / \mathrm{ml}$ and the median was $32 \mathrm{IU} / \mathrm{ml}$.

- The mean value of Anti-CCP titre in the studied group was $303.19 \pm 336.94 \mathrm{IU} / \mathrm{ml}$, the range was 3.7 to $1213 \mathrm{IU} / \mathrm{ml}$ and the median was $194 \mathrm{IU} / \mathrm{ml}$. Table (2).

Table (2): RF and Anti-CCP titre results of the studied group (80 cases) :

\begin{tabular}{|l|l|l|l|}
\hline Variables & Mean & Range & Median \\
\hline RF( I.U/ml) & $82.59 \pm 113.19$ & $<8-512$ & 32 \\
\hline Anti CCP(I.U/ml) & $303.19 \pm 336.94$ & $3.7-1213$ & 194 \\
\hline
\end{tabular}

RF: Rheumatoid factor

Anti CCP: Anti- cyclic citrullinated protein.

Comparison study:

By comparing the results of Anti-CCP and RF, this study demonstrated that there was a high significant difference between RF and Anti-CCP positive and negative results. Table (3), Figure (1).

Table (3): Relation between RF and Anti- CCP:

\begin{tabular}{|l|l|l|l|}
\hline & Anti- CCP $<25$ & Anti- CCP $>25$ & Total \\
\hline $\mathrm{RF}<8$ & 19 & 9 & $28(35 \%)$ \\
\hline $\mathrm{RF}>8$ & 5 & 47 & $52(65 \%)$ \\
\hline Total & $24(30 \%)$ & $56(70 \%)$ & 80 \\
\hline
\end{tabular}

$\mathrm{X} 229.4 \mathrm{p}=0.0000$

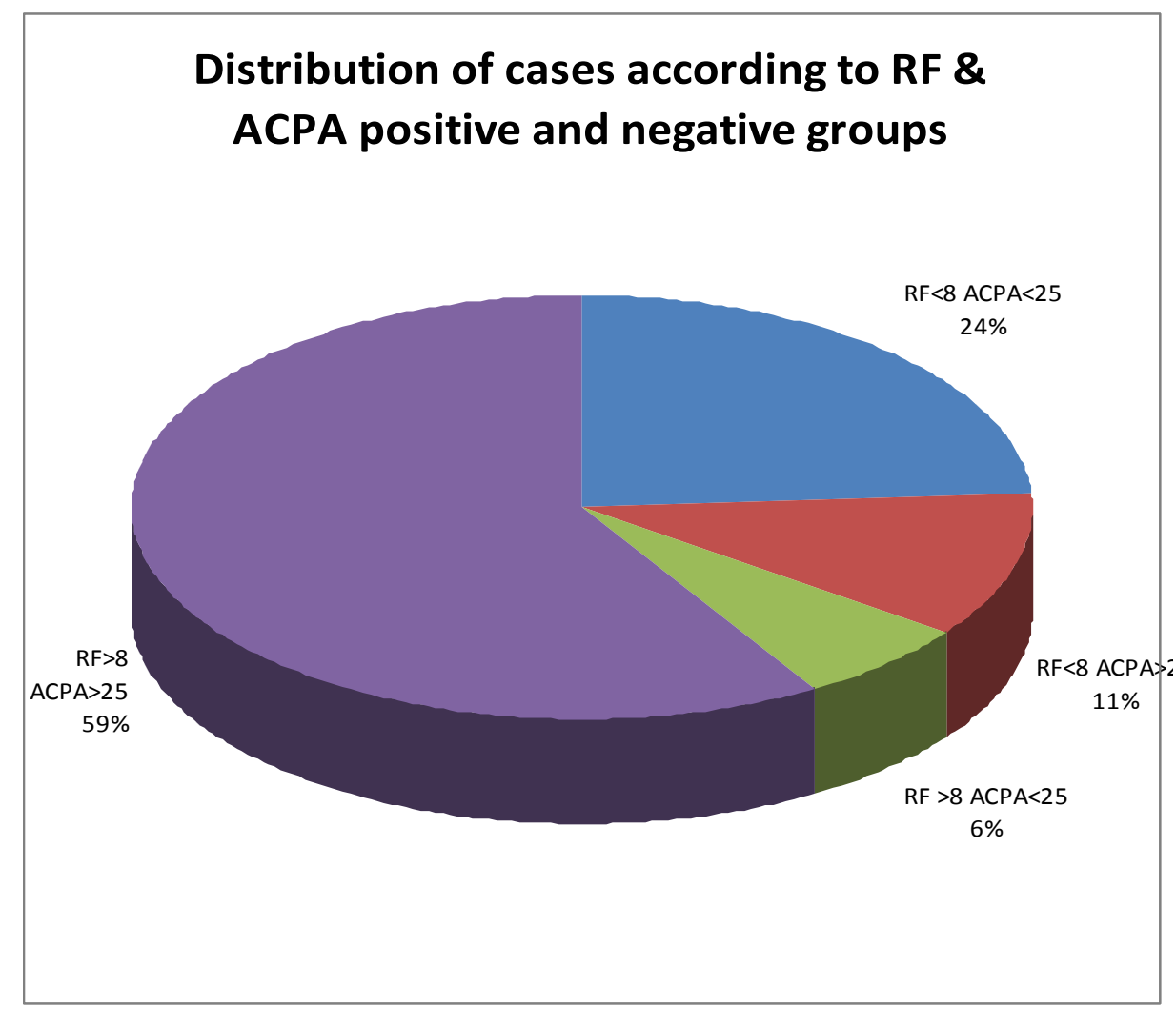

Fig (1): Shows distribution of cases according to RF and Anti-CCP positive and negative groups. 
Table (4): Difference between laboratory scores, pain and severity of disease as regard to positive or negative RF results:

\begin{tabular}{|l|l|l|l|l|}
\hline Variables & $\begin{array}{l}\mathrm{RF}<8 \\
\text { No=28 }\end{array}$ & $\begin{array}{l}\mathrm{RF}>8 \\
\text { No.=52 }\end{array}$ & $\begin{array}{l}\text { Test of } \\
\text { significance }\end{array}$ & $\begin{array}{l}\mathrm{P} \\
\text { value }\end{array}$ \\
\hline Anti-CCP & $110.9 \pm 236.8$ & $406.74 \pm 339.02$ & $\mathrm{t}=4.1$ & 0.0000 \\
Median & 11.65 & 347 & & \\
Range & $3.7-988$ & $5-1213$ & & \\
\hline Sharp score & $26.67 \pm 23.24$ & $23.69 \pm 27.91$ & $\mathrm{t}=0.46$ & 0.6461 \\
Median & 22 & 16 & & \\
Range & $0-92$ & $0-128$ & & \\
\hline HAQ & $36.88 \pm 22.96$ & $40.81 \pm 25.24$ & $\mathrm{t}=0.68$ & 0.4922 \\
Median & 38.75 & 35 & & \\
Range & $0-83.75$ & $2.5-85$ & & \\
\hline ACR class & $1.61 \pm 0.92$ & $2.22 \pm 1.14$ & $\mathrm{t}=2.43$ & 0.0174 \\
Range & $1-4$ & $1-4$ & & \\
\hline VAS & $5 \pm 2.75$ & $6.45 \pm 2.51$ & $\mathrm{t}=2.38$ & 0.0199 \\
Range & $0-10$ & $0-10$ & & \\
\hline DAS28 & $5.29 \pm 1.38$ & $5.39 \pm 1.46$ & $\mathrm{~T}=0.26$ & 0.7955 \\
Range & $2.02-7.35$ & $2.22-7.57$ & & \\
\hline STLW & $26 \pm 12.99$ & $31.37 \pm 22.19$ & $\mathrm{t}=1.17$ & 0.2440 \\
Range & $0-54$ & $0-97$ & & \\
\hline
\end{tabular}

RF: Rheumatoid factor

Anti-CCP: Anti cyclic citrullinated protein antibody

HAQ: Health assessment Questionnaire

ACR Class: American college of Rheumatology disability classification

DAS: Disease activity score

VAS: Visual analogue scale

STLW score: Swelling tenderness limitation of movement warmth

There was high statistical significant difference between positive or negative RF results in Anti-CCP readings.

There was high significant difference between positive or negative RF results in ACR class \& VAS. 
Table (5): Difference between clinical, radiological and disability scores as regard to positive or negative Anti-CCP:

\begin{tabular}{|c|c|c|c|c|}
\hline Variables & $\begin{array}{l}\text { Anti-CCP } \\
<25-\mathrm{No}= \\
24\end{array}$ & $\begin{array}{l}\text { Anti-CCP > } \\
25-\text { No }=56\end{array}$ & $\begin{array}{l}\text { Test of } \\
\text { significance }\end{array}$ & $\mathrm{P}$ value \\
\hline $\begin{array}{l}\text { Sharp } \\
\text { score }\end{array}$ & $18.96 \pm 20.13$ & $27.72 \pm 28.28$ & \multirow[t]{3}{*}{$\mathrm{t}=1.33$} & \multirow[t]{3}{*}{0.1883} \\
\hline Median & 16 & 20 & & \\
\hline Range & $0-92$ & $0-128$ & & \\
\hline HAQ & $37.24 \pm 23.84$ & $40.36 \pm 24.77$ & \multirow[t]{3}{*}{$\mathrm{t}=0.52$} & \multirow[t]{3}{*}{0.6036} \\
\hline Median & 38.12 & 37.5 & & \\
\hline Range & $0-83.75$ & $2.5-85$ & & \\
\hline $\begin{array}{l}\text { ACR } \\
\text { class }\end{array}$ & $1.54 \pm 0.88$ & $2.2 \pm 1.13$ & \multirow[t]{3}{*}{$\mathrm{T}=2.53$} & \multirow[t]{3}{*}{0.0132} \\
\hline Median & 1 & 2 & & \\
\hline Range & $1-4$ & $1-4$ & & \\
\hline VAS & $5.04 \pm 2.49$ & $6.33 \pm 2.67$ & \multirow[t]{3}{*}{$\mathrm{t}=2.01$} & \multirow[t]{3}{*}{0.0485} \\
\hline Median & 5 & 7 & & \\
\hline Range & $0-9$ & $1-10$ & & \\
\hline DAS28 & $5.47 \pm 1.23$ & $5.3 \pm 1.51$ & \multirow[t]{3}{*}{$\mathrm{t}=0.46$} & \multirow[t]{3}{*}{0.6482} \\
\hline Median & 5.63 & 5.4 & & \\
\hline Range & $2.02-7.35$ & $2.22-7.57$ & & \\
\hline STLW & $24.96 \pm 12.08$ & $31.43 \pm 21.79$ & \multirow[t]{3}{*}{$\mathrm{t}=1.36$} & \multirow[t]{3}{*}{0.1764} \\
\hline Median & 23.5 & 29.5 & & \\
\hline Range & $0-54$ & $0-97$ & & \\
\hline
\end{tabular}

Anti-CCP: Anti cyclic citrullinated protein antibody

HAQ: Health assessment Questionnaire

ACR Class: American college of Rheumatology disability classification

DAS: Disease activity score

VAS: Visual analogue scale

STLW score: Swelling tenderness limitation of movement warmth

There was high significant difference between positive or negative Anti-CCP in American College of Rheumatology disability class and in VAS (Visual analogue scale).

\section{Correlation studies:}

A correlation study was performed between the results of RF and Anti-CCP showing significant positive correlation Fig (3)

A correlation between Anti-CCP and clinical, radiological and disability scorers showing the following:

1- There was significant positive correlation between Anti-CCP and ACR disability class.

2- There was significant positive correlation between Anti-CCP and RF results.

3 - There was positive but not significant correlation between Anti-CCP and STLW scores

4 -In addition, there was positive but not significant correlation between Anti-CCP and VAS scores. 
5 -The rest of items showed no statistical correlation. Table (6).

A correlation between Anti-CCP and other Lab results showed

No statistical significant correlation between Anti-CCP and the studied variables table (7).

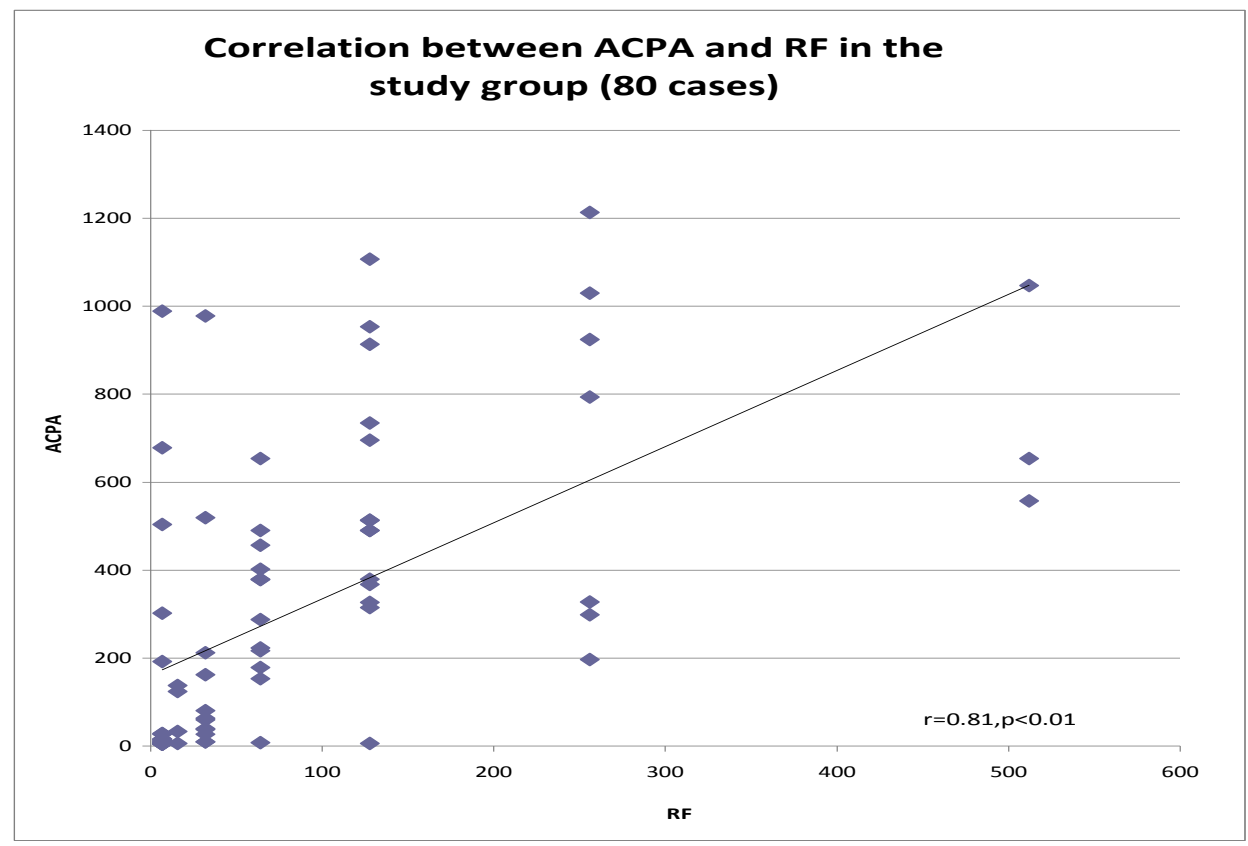

Figure 3: Correlation between Anti-CCP and RF titres of the study group:

Table (6): A correlation between Anti-CCP and clinical, radiological and disability scorers.

\begin{tabular}{|l|l|l|l|}
\hline Correlation- Anti-CCP & $\mathrm{r}$ & $\mathrm{p}$ & Significance \\
\hline Sharp score & 0.07 & $>0.05$ & $\mathrm{NS}$ \\
\hline HAQ & 0.04 & $>0.05$ & $\mathrm{NS}$ \\
\hline ACR class & 0.23 & $<0.05$ & $\mathrm{~S}$ \\
\hline VAS & 0.19 & $>0.05$ & $\mathrm{NS}$ \\
\hline DAS28 & 0.14 & $>0.05$ & $\mathrm{NS}$ \\
\hline STLW & 0.2 & $>0.05$ & $\mathrm{NS}$ \\
\hline RF & 0.81 & $<0.01$ & $\mathrm{~S}$ \\
\hline
\end{tabular}

NS: Not significant

S: Significant

Table (7): A correlation between Anti-CCP and Lab results.

\begin{tabular}{|l|l|l|l|}
\hline Correlation- Anti-CCP & $\mathrm{r}$ & $\mathrm{p}$ & Significance \\
\hline ESR & 0.01 & $>0.05$ & $\mathrm{NS}$ \\
\hline Haemoglobin & 0.04 & $>0.05$ & $\mathrm{NS}$ \\
\hline RBCs count & 0.03 & $>0.05$ & $\mathrm{NS}$ \\
\hline WBCs count & 0.12 & $>0.05$ & $\mathrm{NS}$ \\
\hline Platelets & 0.01 & $>0.05$ & $\mathrm{NS}$ \\
\hline Ceartinine & 0.16 & $>0.05$ & $\mathrm{NS}$ \\
\hline AST & 0.13 & $>0.05$ & $\mathrm{NS}$ \\
\hline ALT & 0.02 & $>0.05$ & $\mathrm{NS}$ \\
\hline
\end{tabular}

RBCs: Red Blood Cells

WBCs: White Blood Cells

AST: Aspartate Transaminase

ALT: Alanine Transaminase 


\section{DISCUSSION}

In the present study we aimed to investigate the vealue of Anti-CCP as a prognostic factor in Rheumatoid Arthritis and compare the results with Rheumatoid factor test.

Eighty female cases of Rheumatoid arthritis within the age group (Range 35 to 40 years old) were enrolled this study. All cases underwent detailed history taking, thorough clinical evaluation including functional impairment, radiological and laboratory assessment. (including Liver function tests, kidney function tests, random blood sugar, CBC, ESR, RF, and Anti-CCP).

Our results showed that there was a statistical significant higher RF titre in Anti-CCP positive patients compared with Anti-CCP negative patients $(\mathrm{p}<0.01)$ (mean value for RF titre was $111.27 \pm 124.25 \mathrm{IU} / \mathrm{ml}$ with positive Anti-CCP and $16.88 \pm 27.09 \mathrm{IU} / \mathrm{ml}$ with negative Anti-CCP), and significant positive correlation between Anti-CCP titre and RF titres $(\mathrm{r}=0.81, \mathrm{p}<0.05)$. Benjamin et al. (2010) made a similar study, Most of his cases were anti-CCP $(75 \%)$ positive and RF (80\%) positive, with a high statistical significant positive correlation between Anti $-\mathrm{CCP}$ and RF $(\mathrm{r}=0.44$, $\mathrm{p}<0.001)$. Kastbom et al. (2004) also studied Anti-CCP and R.F tests titres as predictors of disease course and prognosis and used the same disease duration as our study ( 3 years) but he used about 3 times the number of patients (242). Their results showed there was a significant propensity for Anti-CCP antibody positive patients to be positive also for $\mathrm{RF}(\mathrm{p}=0.001)$ with $78 \%$ of the RF positive and $40 \%$ of the RF negative patients were Anti-CCP antibody positive. They also concluded that Anti-CCP was better as a predictor of the disease course over 3 years than rheumatoid factor. Nehir et al. (2006) also found a significant correlation between the levels of Anti$\mathrm{CCP}$ and $\mathrm{RF}(\mathrm{r}=0.57, \mathrm{p}<0.001)$.

Our results showed a statistically significant difference between positive and negative Anti-CCP and ACR disability classification (ACR class was higher with positive than with negative Anti-CCP) and a significant positive correlation between Anti-CCP titre and ACR disability classification. In their study, Farragher et $\boldsymbol{a l}$. (2010) made a similar study over a period of five years, patients who were anti-CCP positive had a mean change on their HAQ scores of 0.20 points (95\% CI 0.09 to 0.31 ), which reflected a worsening of functional disability. Those who were negative for the antibodies had no worsening in HAQ score, with a mean change of 0.005 (95\% CI -0.06 to 0.07$)$. Although they used the HAQ itself as a measure for functional status/disability over a slightly longer disease duration than in our study (5 years), their results came in accordance with ours as it showed strong positive correlation between positive Anti-CCP test and disability. Nehir et al. (2006) found by logistic regression analysis that only the HAQ score (functional disability) and the duration of morning stiffness are the variables significantly associated with anti-CCP positivity in patients with advanced RA, anti-CCP positive RA patients had more functional disability than anti-CCP negative ones according to HAQ.

Our results showed a statistically significant difference between positive and negative Anti-CCP with VAS (Visual Analogue Scale), with a mean VAS score of 5.04 \pm 2.49 with negative APCA and 6.33 \pm 2.67 with positive Anti-CCP (test of significance $=2.01, \mathrm{p}=$ $<0.05)$. Landmann et al. (2010) who correlated the level of anti-CCP and disease activity using the DAS-28, as in our study and used, a patient-reported visual analog scale (VAS) score, and the ESR. They found a significant positive correlation between Anti-CCP and VAS. On the other hand, Nehir et al. (2006) found no significant correlation between VAS and anti CCP titres, but detected a higher VAS score in Anti-CCP positive patients compared to Anti-CCP negative patients with a difference in mean of $30.1 \pm 29.4$ vs $19.7 \pm 20.6$ respectively. 
Our study revealed that Anti-CCP has almost the exact same predictive value as that given by R.F. Lindqvist $\boldsymbol{e t}$ al. (2005) found in a study of patients with early arthritis, that baseline values of anti-CCP (67\%) and RF (69\%) showed similar sensitivity for prediction of radiographic progression at 5 years, but they did not test disability and functional status. Yasser et al. (2010) found a positive correlation between Anti-CCP titre with clinical severity and functional disability, but did not express difference between findings of positive Anti-CCP and positive R.F.

We found that anti-CCP is a good prognostic marker for Rheumatoid arthritis patients especially with disability prediction, and gave more or less similar predictive values with Rheumatoid factor. The strongly positive correlation between the titres of both tests shows that they are likely to be similar with patients of different grades of severity. This agrees with the conclusion found by Yasser et al. (2010). Who found that the currently available data suggested that anti-CCP is of good prognostic value besides RF. This is in contrast to Zendman et al. (2006). Who found that Anti-CCP positivity has prognostic potential, but the absolute level of anti-CCP has not been demonstrated to be a useful measure of future severity of disease. Our results also disagree with Lindqvist et al. (2005). who stated that combining RF with anti-CCP results appeared to help in prediction: $\mathrm{RF}+/$ anti-CCP+ patients had greater progression than $\mathrm{RF}+/$ anti-CCP- and $\mathrm{RF}-/ \mathrm{CCP}-$ patients at 5 years, while in our study, the subgroup analysis of RF and Anti-CCP positive and negative combinations did not yield additional data than that of Anti-CCP positive versus Anti-CCP negative alone.

Limitations: The number of patients in the study group was small when compared to similar studies, and so did not allow better analysis of the findings. Also, the disease duration of the study group was short when compared to similar studies.

The main limitation of the Health Assessment Questionnaire used in our study was that it was not tailored for Egyptian lifestyle especially the low socioeconomic levels and the illiteracy of many of the patients in our study group prevented them from reading and filling the Questionnaire themselves (although it was translated into Arabic), which hampered the accuracy of the results. Radiographic and clinical assessment of the cases including DAS score calculation was not done periodically (once at baseline then once again every year as in most similar studies) to enable more accurate detection of progression and severity. In addition, specialized radiologists were not involved in the study for a better estimation of the radiographic score.

\section{REFERENCES}

Aletaha, D.; Stamm, T. and Smolen, J.S. (2004): Validation of the Simplified Disease Activity Index (SDAI) in an observational cohort of patients with rheumatoid arthritis. Annals of the Rheumatic Diseases; 1: 5111.

Arnett F, Edworthy S, Bloch D, McShane D, Fries J et al. (March 1988): "The American Rheumatism Association 1987 revised criteria for the classification of rheumatoid arthritis.".Arthritis.Rheum:31(3):315-24.

Benjamin J Miriovsky, Kaleb Michaud, Geoffrey M Thiele, et al. (2010): Ann Rheum Dis 2010; 69:1292-7.

Farragher T, Mark L, Darren P, Diane K et al. (2010): "Benefit of early treatment in inflammatory polyarthritis patients with anti-cyclic citrullinated peptide antibodies versus those without antibodies" Arthritis Care Res; 62: 664-75. 
Hochberg MC et al. (1992): Guidelines for Medical Management of Rheumatoid Arthritis Arthritis Rheum 35:498.

Jansen AL, van der Horst-Bruinsma I, van Schaardenburg D (2002): Rheumatoid factor and antibodies to cyclic citrullinated peptide differentiate rheumatoid arthritis from undifferentiated polyarthritis in patients with early arthritis. J Rheumatol; 29: 2074-6.

Kastbom A, Strandberg G, Lindroos A, Skogh T (2004): Anti-CCP antibody test predicts the disease course during 3 years in early rheumatoid arthritis (the Swedish TIRA project). Ann Rheum Dis 2004; 63:1085-89.

Kroot EJ, M van Leeuwenb, M van Rijswijkb, M L Prevooa, M Van't Hofa, L van de Putte (2000): No increased mortality in patients with rheumatoid arthritis: up to 10 years of follow up from disease onset. Arthritis Rheum; 43:1831-5.

Landmann T, Kehl G, Bergner R. (2010): The continuous measurement of anti-CCPantibodies does not help to evaluate the disease activity in anti-CCP-antibodypositive patients with rheumatoid arthritis. Clin Rheumatol; 29(12):1449-53.

Lindqvist E, Eberhardt K, Bendtzen K, Heinegard D, Saxne T (2005): Prognostic laboratory markers of joint damage in rheumatoid arthritis. Ann Rheum Dis; 64:196-201.

Majithia V, Geraci SA. (2007): Rheumatoid arthritis: diagnosis and management. Am J Med; 120:936-939.

Nehir Samanci, MD; Sebahat Ozdem, MD; Halide Akbas, MD; Derya Mutlu, MD et al. (2006): Diagnostic Value and Clinical Significance of Anti-CCP in Patients with Advanced Rheumatoid Arthritis, J Natl Med Assoc.; 97:1120-6.

Prevoo ML, van 't Hof MA, Kuper HH, van Leeuwen MA, van de Putte LB, van Riel PL. (1995): Modified disease activity scores that include twenty-eight joints counts. Arthritis and Rheumatism; 38:44-8.

Schellekens GA, de Jong BAW, van den hoogen FHJ, van de Putte LBA (1998): Citrulline is an essential constituent of antigenic determinants recognized by rheumatoid arthritis specific autoantibodies. J Clin Invest; 101:273-81.

Sharp JT, Young DY, Bluhm GB, et al. (1985): How many joints in the hands and wrists should be included in a score of radiologic abnormalities used to assess rheumatoid arthritis? Arthritis Rheum; 28:1326-35.

Van der Heijde D (1999): How to read radiographs according to the Sharp/van der Heijde method. J Rheumatol; 26:743-5.

Van Der Heijde DMFM, Van't Hof MA, Van Riel PLCM, Van Der Putte LBA (1993): Development of a disease activity score based on judgment in clinical practice by rheumatologists. J. Rheumatol; 20:579-81.

Yasser Emad, Mohamed Shehata, Yasser Ragab, Ahmed Saad, Hosny Hamza, Alaa Abou-Zeid. (2010): Prevalence and predictive value of anti-cyclic citrullinated protein antibodies for future development of rheumatoid arthritis in early undifferentiated arthritis; Mod Rheumatol 20: 358-65.

Yelin E, Henke C, Epstein W (1999): The work dynamics of the person with rheumatoid arthritis. Arthritis Rheum;30(5):507-512. 
Zendman AJ,Van Venrooij WJ, Pruijn GJ (2006): Use and significance of anti-CCP autoantibodies in rheumatoid arthritis. Rheumatology; 45(1):20-5.

\section{القيمة التكهنية لاختبار الاجسام المضادة للبروتين السترولينى فى الالتهاب المفصلى الروماتويلى}

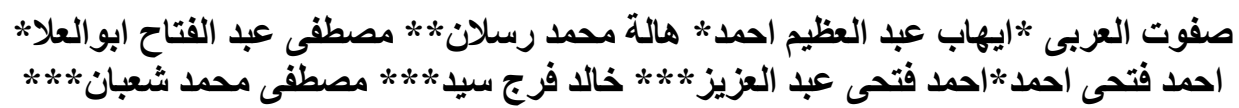

*قسم الروماتيزم بطب الازهر **قم الباطنة بالمركز القومى للبحوث***قسم الباثولوجيا الاكلينيكية بطب الازهر

مرض التهاب المفاصلل الروماتويدى هو التهاب مزمن يؤثر على العديد من الانسجة و الاعضاء ولئ ولكنه يهاجم

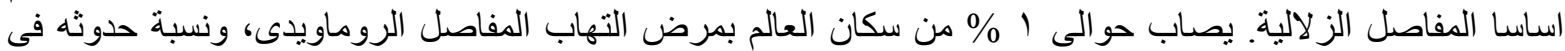

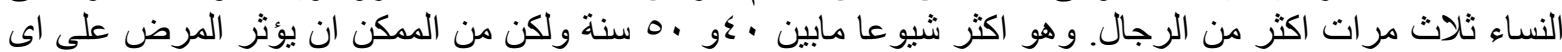

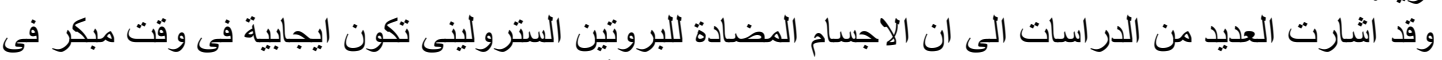
مرحلة عمرية.

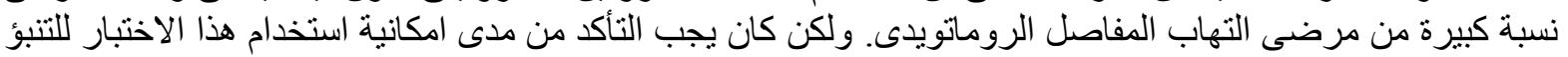

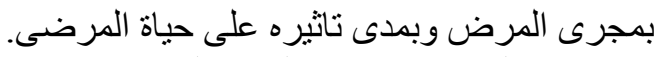
ولقد اجرى هذا البحث لدراسة قيمة اختبار الاجسام المضادة للبروتين السترولينى فى مرضى مرضى الالتهاب

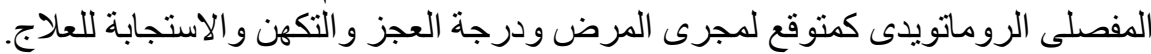

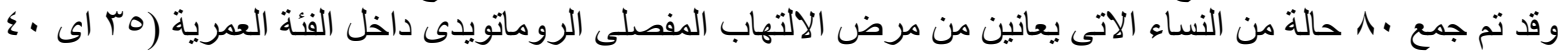

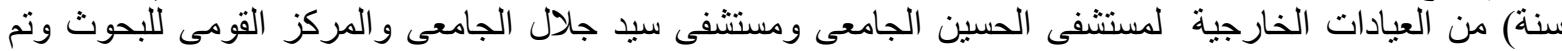
تشخيص الحالات بمعرفة اطباء الروماتيزم و الطب الطبئ الطبيعى و التاهيل.

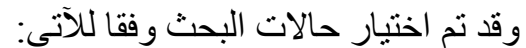

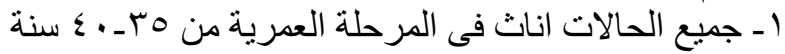

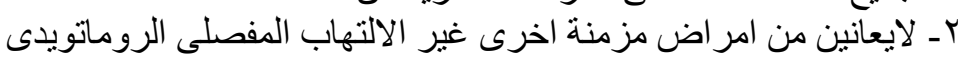

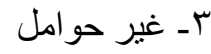
ـ ـ مدة المعاناة من الالتهاب المفصلى الروماتويدى تتراوح مابين ب الى ه سنوات منذ ظهور الاعراض التشخيصية

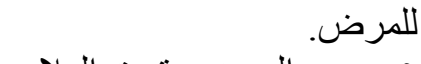
0 - مقيع المرضى تحت العلاج.

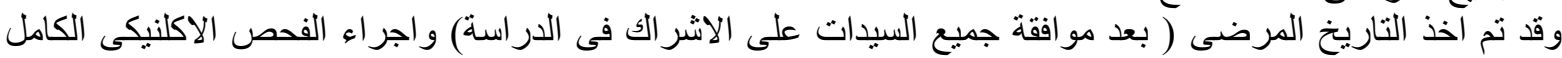

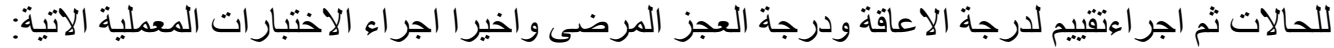

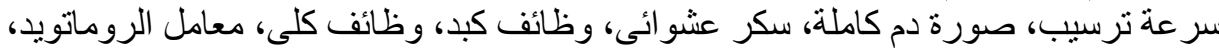

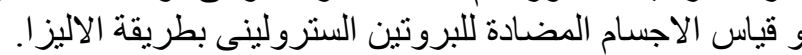

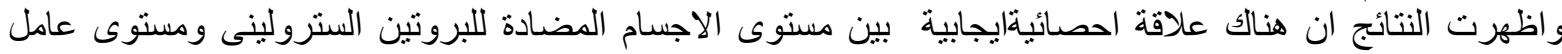

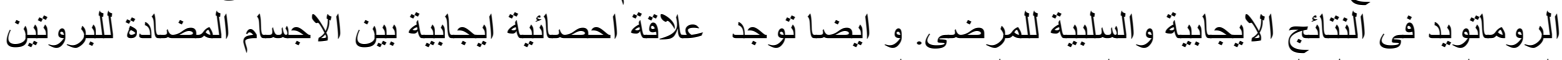

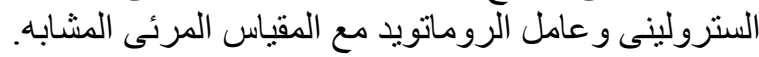

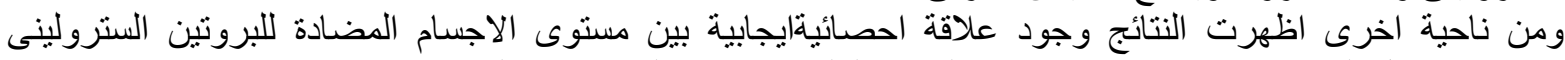

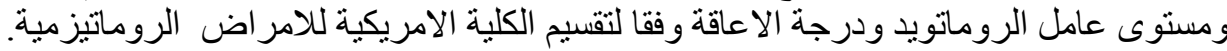

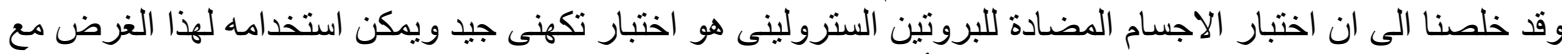

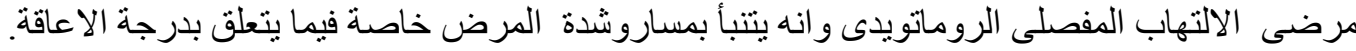

